\title{
POJĘCIE PRACODAWCY W RAZIE PRZEJŚCIA ZAKŁADU PRACY
}

\section{UWAGI OGÓLNE}

W myśl art. $23^{1} \S 1$ k.p. w razie przejścia zakładu pracy lub jego części na innego pracodawcę, pracodawca ten staje się z mocy prawa stroną w dotychczasowych stosunkach pracy. Wyjątek dotyczy pracowników zatrudnionych na innej podstawie niż umowa o pracę (art. $23^{1} \S 5$ k.p.). Przejście zakładu pracy lub jego części wiąże się ze zmianą podmiotową po stronie pracodawcy ${ }^{1}$. Skutek w postaci wstapienia nowego pracodawcy w stosunki pracy w miejsce dotychczasowego pracodawcy nie może być przez strony uczestniczące w transferze w żaden sposób modyfikowany ani uchylony, w szczególności w drodze umowy cywilnoprawnej ${ }^{2}$.

Istotnym zagadnieniem wydaje się przeanalizowanie znaczenia pojęcia pracodawcy w aspekcie przejścia zakładu pracy lub jego części na innego pracodawcę. Zgodnie z art. 3 k.p., za ,pracodawcę” uważana jest każda jednostka organizacyjna, chociażby nie posiadała osobowości prawnej, a także osoba fizyczna, jeżeli zatrudniają one pracowników. Niemniej w praktyce nie zawsze podmioty lub osoby, które przejmują zakład pracy lub jego część, mają status pracodawcy przed przejściem zakładu pracy lub jego części, np. osoba fizyczna

Dr Ewelina KumOR-JeZIERSKA - adwokat, asystent Katedry Prawa Pracy i Polityki Społecznej, Wydział Prawa i Administracji Uniwersytetu Jagiellońskiego, ul. Grodzka 53, 31-001 Kraków; e-mail: ewelina.kumor-jezierska@uj.edu.pl

${ }^{1}$ P. Zawirska, M. ZwolińsKa, Proeuropejska wyktadnia pojęcia przejścia zakladu pracy kryterium tożsamości, „Monitor Prawa Pracy” 2010, nr 8, s. 403.

${ }^{2}$ Wyrok SN z dnia 9 marca 2010 roku, sygn. akt I UK 326/2009, LexPolonica nr 2396068. 
prowadząca jednoosobową działalność gospodarczą nie musi zatrudniać pracowników, podobnie często spadkobierca zanim odziedziczył zakład pracy nie był pracodawcą. W związku z tym występują wątpliwości, jak należy rozumieć znaczenie „innego pracodawcy”, o którym mowa w art. $23^{1} \S 1$ k.p. Kluczowa jest odpowiedź na pytanie, czy musi on posiadać status pracodawcy już w momencie przejścia zakładu pracy lub jego części, czy wystarczy, iż status ten uzyskuje dopiero w momencie, kiedy przejmie pracowników wraz z zakładem pracy, lub wraz z częścią zakładu pracy, i takie „przekształcenie” jest wystarczające do uznania go za „innego pracodawcę”.

\section{POJĘCIE ZAKŁADU PRACY}

W pierwszej kolejności należy zwrócić uwagę, iż pojęcia „zakład pracy” i „pracodawca” nie są synonimami. Jak wskazuje się w doktrynie, określenie „pracodawca” zdefiniowane w art. 3 k.p. zostało wprowadzone dla oznaczenia każdego podmiotu zdolnego do zatrudniania pracowników ${ }^{3}$. Nie ma też znaczenia cel, w jakim zatrudniani są pracownicy. Może to być cel gospodarczy jak i niegospodarczy ${ }^{4}$. Jednostka organizacyjna ma przymiot pracodawcy bez względu na to, czy posiada osobowość prawną. W doktrynie uważa się, że w przypadku jednostek organizacyjnych, które mają rozbudowaną strukturę, przymiot pracodawcy w rozumieniu art. 3 k.p. ma każda jednostka, której kierownik ma prawo zatrudniać i zwalniać pracowników. A. Świątkowski wskazuje, że uprawnienia władcze kierowników zakładów pracy do zatrudniania i zwalniania pracowników świadczą o samodzielności finansowej i organizacyjnej oraz o wyodrębnieniu majątkowym podmiotów uprawnionych do samodzielnego i we własnym imieniu zatrudniania pracowników. Sa wyznacznikiem statusu pracodawcy tych podmiotów $\mathrm{w}$ stosunkach prawnych regulowanych przepisami indywidualnego i zbiorowego prawa pracy $^{5}$. Przykładowo - nie można uznać za pracodawcę jednostki organizacyjnej, której kierownik przyjmuje i zwalnia pracowników wyłącznie na podstawie upoważnienia, jak to ma

\footnotetext{
${ }^{3}$ A.M. ŚWiątKowski, Kodeks pracy. Komentarz, Warszawa 2010, s. 12.

${ }^{4}$ K. RĄcZKa [w:] M. Gersdorf, K. RĄCZKA, J. SkocZYŃSKI, Kodeks pracy. Komentarz (Wielkie Komentarze), Warszawa 2011, s. 21.

5 A.M. ŚwiątKowsKi, Kodeks pracy, s. 12; zob. szerzej P. WĄż, Koncepcja pracodawcy rzeczywistego w świetle art. 3 KP, „Monitor Prawa Pracy” 2007, nr 3.
} 
miejsce często na budowach, w punktach usługowych ${ }^{6}$. Należy też wskazać, iż w literaturze przedmiotu waspekcie analizy terminologicznej podnosi się, że de lege lata statusu pracodawcy nie ma zakład pracy. Pojęcie to ma obecnie przede wszystkim znaczenie przedmiotowe, a posługiwanie się pojęciem zakładu pracy w wymiarze podmiotowym jest normatywnie nieuprawnione ${ }^{7}$. Podobnie SN w wyroku z 23 lutego 1999 r. ${ }^{8}$ uznał także, że nie jest pracodawcą jednostka organizacyjna wyznaczona jako miejsce pracy.

Pojęcie ,zakładu pracy” jest używane w znaczeniu przedmiotowym. Niemniej jednak w tym znaczeniu zakład pracy nie został zdefiniowany w Kodeksie pracy. Wykładnię tego terminu ustalają doktryna i orzecznictwo na podstawie przepisów, w których ono występuje. W piśmiennictwie trafnie wskazuje się, że o uznaniu konkretnej jednostki za zakład pracy przesądzają te elementy (materialne i niematerialne), które umożliwiają wykonywanie pracy przez zatrudnionych pracowników, a zatem powoduja, że stanowi on placówkę zatrudnienia ${ }^{9}$. Zakład pracy zatem w kontekście art. $23^{1} \mathrm{k}$.p. należy rozumieć głównie w ujęciu przedmiotowym, jako jednostkę techniczno-organizacyjną będącą placówką zatrudnienia. Jest zorganizowaną całościa, na którą składają się określone elementy materialne, np. nieruchomości, sprzęt w postaci urządzeń, maszyn, samochodów, jak i elementy niematerialne, np. prawa autorskie, znaki towarowe, wzory użytkowe i zdobnicze, kontakty handlowe, a także odrębna struktura organizacji pracy i zarządzania, zespół pracowników ${ }^{10}$. Przy czym należy zaznaczyć, iż człowiek nie może być przedmiotem obrotu. Jednakże określony kompleks majątkowy staje się ,,zakładem pracy” objętym regulacjami prawa pracy tylko wtedy, kiedy zadania, dla których powstał, są wykonywane przy pomocy

${ }^{6}$ W. Muszalski [w:] W. Muszalski (red.), G. GoźDZiewicz, M. NaŁęcz, W. Patulski, K. WALCZAK, Kodeks pracy. Komentarz, Warszawa 2011, s. 18.

${ }^{7}$ K.W. Baran [w:] K.W. Baran (red.), B.M. Ćwiertniak, S. Driczinski, Z. Góral, A. Kosut, W. Perdeus, J. Piątkowski, M. Skąpski, M. Tomaszewska, M. WŁodarczyk, T. Wyka, Kodeks pracy. Komentarz, Warszawa 2012, s. 32; zob. także A. SовCZYK, Uwagi na temat praw pracodawcy w polskim prawie pracy, Studia z zakresu prawa pracy i polityki społecznej 1995, s. 211-212.

${ }^{8}$ Wyrok SN z dnia 23 lutego 1999 roku, sygn. akt I PKN 594/98, LEX nr 37482.

${ }^{9}$ Z. HaJn, Pojęcie pracodawcy po nowelizacji kodeksu pracy, „Praca i Zabezpieczenie Społeczne" 1997, nr 5-6, s. 25.

${ }^{10}$ Zob. E. Suknarowska-Drzewiecka [w:] K. Walczak (red.), Kodeks pracy. Komentarz, Legalis 2015, kom. do art. 231 , teza 10; por. J. Stelina [w:] A. SobCZYK (red.), D. Dörre-KolasA, M. GŁadoch, P. Korus, L. Mitrus, M. ZiElenieCKi, Kodeks pracy. Komentarz, Warszawa 2015, s. 107. 
pracowników ${ }^{11}$. Ponadto w orzecznictwie SN można znaleźć definicję „zakładu pracy" w kontekście przejścia na innego pracodawcę, rozumianego nie tylko jako zorganizowany zespół składników materialnych, ale także zakład pracy rozumiany przez zadania, które wykonuje ${ }^{12}$.

Potocznie pojęcie zakładu pracy jest niekiedy utożsamiane $\mathrm{z}$ pojęciem przedsiębiorstwa. Jednakże nie są to pojęcia równoznaczne. Zasadnicza różnica widoczna jest w zakresie celów, do których te dwa terminy są używane. Zakład pracy realizuje cele związane z procesem pracy. Pod pojęciem tym rozumie się, jak już wspomniano, zespół elementów materialnych i niematerialnych, które umożliwiaja pracodawcy prowadzenie określonej działalności, ale jest przede wszystkim miejscem zatrudnienia dla związanych z nim pracowników. Natomiast przedsiębiorstwo realizuje cel gospodarczy. Jego definicja znajduje się w art. $55^{1}$ k.c. Kodeks cywilny za przedsiębiorstwo uznaje zorganizowany zespół składników niematerialnych i materialnych przeznaczony do prowadzenia działalności gospodarczej ${ }^{13}$. W doktrynie wyróżnia się na ogół trzy znaczenia pojęcia „przedsiębiorstwa”, tj. podmiotowe, funkcjonalne i przedmiotowe. W znaczeniu podmiotowym przedsiębiorstwo traktowane jest jako wyodrębnienie pewnej masy majątkowej i powiązanie jej $\mathrm{z}$ określoną osobą prawną, która w obrocie występuje jako podmiot stosunków prawnych. W ujęciu funkcjonalnym termin ten oznacza pewną określoną działalność gospodarcza, zarobkowa, celową i o charakterze zawodowym. $Z$ kolei w aspekcie przedmiotowym oznacza kompleks majątkowy zdefiniowany w art. $55^{1}$ k.c., i w takim znaczeniu przedsiębiorstwo występuje jako przedmiot stosunku cywilnoprawnego ${ }^{14}$. W przedsiębiorstwie mogą być zatrudnieni pracownicy, ale dla bytu przed-

\footnotetext{
${ }^{11}$ T. Liszcz, Prawo pracy, Warszawa 2014, s. 110,111.

12 Wyrok SN z dnia 20 października 2009 roku, sygn. akt I PK 96/2009, LexPolonica nr 2375700, Legalis nr 288285.

${ }^{13}$ Obejmuje ono w szczególności oznaczenie indywidualizujące przedsiębiorstwo lub jego wyodrębnione części (nazwa przedsiębiorstwa); własność nieruchomości lub ruchomości, w tym urządzeń, materiałów, towarów i wyrobów, oraz inne prawa rzeczowe do nieruchomości lub ruchomości; prawa wynikające z umów najmu i dzierżawy nieruchomości lub ruchomości oraz prawa do korzystania z nieruchomości lub ruchomości wynikające z innych stosunków prawnych; wierzytelności, prawa z papierów wartościowych i środki pieniężne; koncesje, licencje i zezwolenia; patenty i inne prawa własności przemysłowej; majątkowe prawa autorskie i majątkowe prawa pokrewne; tajemnice przedsiębiorstwa; księgi i dokumenty związane z prowadzeniem działalności gospodarczej.

${ }^{14}$ Z. Gawlik [w:] A. Kidyba (red.), A. JaniaK, A. Jedliński, K. KopaczyńsKa-Pieczniak, E. NiezBeCKA, T. SoKoŁowski, Kodeks cywilny. Komentarz, t. I: Część ogólna, Warszawa 2012, s. $294,295$.
} 
siębiorstwa nie jest to konieczne, gdyż przedsiębiorstwo może funkcjonować bez pracowników. Oznacza to, z tego punktu widzenia, że nie każde przedsiębiorstwo jest zakładem pracy (np. przedsiębiorstwo prowadzone w formie jednoosobowej działalności gospodarczej niezatrudniające pracowników), jak również nie każdy zakład pracy jest przedsiębiorstwem, np. urzędy państwowe, partie polityczne, które nie prowadzą działalności gospodarczej. Należy zaznaczyć, iż ponadto istnieją podmioty, które nie są ani przedsiębiorstwem, ani zakładem pracy, a tylko np. osobą fizyczną. W takim wypadku nie ma zastosowania art. $23^{1}$ k.p., ponieważ nie ma pracowników, którzy mogliby zostać objęci ochroną tego przepisu.

\section{CZĘŚĆ ZAKŁADU PRACY}

W Kodeksie pracy w art. $23^{1} \S 1$ k.p. ustawodawca zapewnia ochronę pracownikom także przy przejściu „części zakładu pracy” na innego pracodawcę. Niemniej ustawodawca nie określa precyzyjnie, co należy rozumieć pod pojęciem „części zakładu pracy”, ani jakie elementy składają się na nią. Określenie tego terminu ma doniosłe znaczenie dla każdego nabywcy, gdyż musi on jednoznacznie ocenić, czy nabywany przez niego majątek stanowi już część zakładu pracy, czy może są to tylko pojedyncze składniki majątkowe tego zakładu pracy. Jest to o tyle istotne, że pozwoli na ocenę, czy nowy podmiot nabywający jest już związany konsekwencjami wynikającymi z art. $23^{1}$ k.p. w stosunku do pracowników, którzy ewentualnie mogą zostać automatycznie przejęci wraz z transferem.

W doktrynie wskazuje się, że dla wyodrębnienia części zakładu pracy nie jest istotny tylko materialny aspekt, ale także to, czy jest ona na tyle wyodrębniona organizacyjnie w ramach całego zakładu pracy, że stanowi placówkę zatrudnienia dla pracowników z nią związanych i tworzy wraz z nimi integralną całość $^{15}$. Cenną wskazówkę w interpretacji tego pojęcia można znaleźć także w wyroku SN z dnia 20 listopada 1996 r. ${ }^{16}$, w którym sąd uznał, iż przez „część zakładu pracy" w rozumieniu art. $23^{1}$ k.p. nie należy rozumieć każdego składnika mienia dotychczasowego pracodawcy, jak np. lokalu, maszyny, określo-

\footnotetext{
${ }^{15}$ R. NADSKAKULSKI, Część zakładu pracy w rozumieniu wybranych przepisów prawa pracy, „Praca i Zabezpieczenie Społeczne” 1995, nr 10, s. 29; zob. szerzej: W. SANETRA, O pojęciu części zakladu pracy, „Przegląd Sądowy” 1994, nr 1, s. 3 i n.

${ }^{16}$ Wyrok SN z dnia 20 listopada 1996 roku, sygn. akt I PKN 21/96, LEX nr 192324.
} 
nego prawa majątkowego. Zdaniem SN częścią zakładu pracy staną się one dopiero wówczas, gdy będą tworzyć zespół składników zakładu, który może być potraktowany jako odrębna placówka zatrudnienia dla pracowników, którzy wykonują w niej pracę. Musi być to zatem pewna zorganizowana całość, na którą składają się określone elementy materialne i majątkowe, system organizacyjny i struktura zarządzania, które to elementy będą dawały możliwość dalszego wykonywania pracy przez pracowników w niej zatrudnionych. Po ustaleniu, że mamy do czynienia z częścią zakładu pracy w rozumieniu art. $23^{1}$ k.p., może pojawić się kolejny problem, tym razem z określeniem, którzy pracownicy zostają przejęci przez nowego pracodawcę wraz z częścią zakładu. W tej kwestii SN wypowiedział się w wyroku z 2 października 1996 r. $^{17}$, uznając, że będą to wszyscy pracownicy, którzy byli związani przedmiotem swego zobowiązania z działalnością przejmowanej części zakładu. Co więcej, skutek ten nie zależy od liczby zatrudnionych pracowników w zakładzie pracy i może obejmować nawet jedną osobę. Natomiast jeżeli związanie pracownika z przejętą częścią zakładu pracy jest niemożliwe do ustalenia, to zmiana pracodawcy nie dotyczy tego pracownika ${ }^{18}$. Oznacza to, iż decyzja, czy dany pracownik zostaje przejęty wraz z częścią zakładu pracy przez inny podmiot, nie zależy od uznania dotychczasowego i nowego pracodawcy, tylko od okoliczności faktycznych, i przejęcie to następuje w takim wypadku w sposób automatyczny ${ }^{19}$. Co więcej, w razie przejęcia zakładu pracy w części przez innego pracodawcę, staje się on z mocy prawa stroną w stosunkach pracy z pracownikami zatrudnionymi w przejętej części zakładu także wówczas, gdy pracownicy ci sprzeciwiali się zmianie pracodawcy ${ }^{20}$.

W praktyce często mają miejsce takie transakcje, gdzie nabywca kupuje nie całe przedsiębiorstwo, tylko zorganizowaną część przedsiębiorstwa, w którym zatrudnieni są pracownicy. Definicja zorganizowanej części przedsiębiorstwa znajduje się w ustawie o podatku dochodowym od osób fizycznych i w ustawie o podatku dochodowym od osób prawnych. Pojęcie zorganizowanej części przedsiębiorstwa ustawodawca definiuje jako wyodrębniony organizacyjnie i finansowo w istniejącym przedsiębiorstwie zespół składników materialnych i niematerialnych, w tym jego zobowiązania, przeznaczonych do realizacji określo-

\footnotetext{
${ }^{17}$ Wyrok SN z dnia 2 października 1996 roku, sygn. akt I PRN 72/96, LexPolonica nr 314288, LEX nr 27469.

${ }^{18}$ Wyrok SN z dnia 3 kwietnia 2007 roku, sygn. akt II PK 245/2006, LexPolonica nr 1631760.

${ }^{19}$ Por. Wyrok SN z dnia 21 stycznia 2011 r., sygn. akt II PK 223/10, Legalis nr 417505.

${ }^{20}$ Wyrok SN z dnia 19 stycznia 1993 roku, sygn. akt I PZP 70/92, LexPolonica nr 300595.
} 
nych zadań gospodarczych, który zarazem mógłby stanowić niezależne przedsiębiorstwo samodzielnie realizujące te zadania ${ }^{21}$. W zorganizowanej części przedsiębiorstwa mogą być zatrudnieni pracownicy, ale bytu tej struktury ustawodawca nie uzależnia od zatrudnienia pracowników, jako elementu koniecznego do uznania, że jest to zorganizowana część przedsiębiorstwa. Niemniej jeżeli w zorganizowanej części przedsiębiorstwa będą zatrudnieni pracownicy i na podstawie różnych transakcji (np. przeniesienia własności lub tylko posiadania) dojdzie do zmiany podmiotu zatrudniającego, to w takim wypadku znajdzie zastosowanie konstrukcja wskazana $\mathrm{w}$ art. $23^{1}$ k.p. Oznacza to $\mathrm{z}$ tego punktu widzenia, że nie każda zorganizowana część przedsiębiorstwa jest częścią zakładu pracy, jak również nie każda część zakładu pracy jest zorganizowaną częścią przedsiębiorstwa.

\section{INNY PRACODAWCA}

Przepis art. $23^{1}$ k.p. stanowi, iż „,w razie przejścia zakładu pracy lub jego części na innego pracodawcę staje się on $\mathrm{z}$ mocy prawa stroną $\mathrm{w}$ dotychczasowych stosunkach pracy [...]". Jak już wspomniano, ustawodawca legalną definicję pracodawcy zawarł w art. 3 k.p. Cechą pracodawcy jest zdolność do zatrudniania pracowników, jednakże sama zdolność do zatrudniania nie oznacza jeszcze, że dany podmiot jest pracodawcą. Status pracodawcy uzyskuje dopiero podmiot rzeczywiście zatrudniający pracowników. Przepis art. 3 k.p. stanowi o zatrudnianiu pracowników (w liczbie mnogiej), ale w doktrynie przyjmuje się, że podmiot zatrudniający już nawet jednego pracownika spełnia definicję pracodawcy $^{22}$. A contrario, jeżeli istniejący podmiot nie zatrudnia w ogóle pracowników, nie jest pracodawcą. Przyjmując zatem wyłącznie językową wykładnię niniejszego przepisu, można by dojść do wniosku, iż ustawodawca przewiduje

\footnotetext{
${ }^{21}$ Art. 5a pkt 4 ustawy z dnia z dnia 26 lipca 1991 roku o podatku dochodowym od osób fizycznych (Dz. U. 2012, poz. 361), art. 4a pkt 4 ustawy z dnia 15 lutego 1992 roku o podatku dochodowym od osób prawnych (Dz. U. 2014, poz. 851). Należy też wskazać, iż definicja zorganizowanej części przedsiębiorstwa znajduje się również w art. 2 pkt 27e ustawy z dnia 11 marca 2004 rok o podatku od towarów i usług (Dz. U. 2011, Nr 177, poz. 1054). Dodać należy, że terminem „Zorganizowana część przedsiębiorstwa” posługują się również przepisy Kodeksu spółek handlowych w kontekście zbycia albo wydzierżawienia zorganizowanej części przedsiębiorstwa (art. 228 pkt 3, art. 393 pkt $3 \mathrm{KSH}$ ).

${ }^{22}$ Zob. J. WratnY, Kodeks pracy. Komentarz, Warszawa 2013, s. 7; K.W. Baran [w:] K.W. BARAN (red.), Kodeks pracy, s. 31.
} 
zastosowanie konstrukcji przejścia zakładu pracy lub jego części tylko w sytuacji, kiedy podmiot przejmujący zakład pracy lub tylko jego część jest pracodawca, a więc zatrudniającym co najmniej jednego pracownika. W literaturze utrzymuje się, iż wykładnia językowa i znaczenie literalne w państwach demokratycznych zajmują uprzywilejowana pozycję wobec wykładni systemowej i funkcjonalnej. Jeżeli ustawodawca nadał określonym wyrażeniom znaczenie swoiste, to należy je rozumieć w takim znaczeniu (domniemanie języka prawnego $)^{23}$.

Jednakże akceptacja wyłącznie językowej wykładni tego przepisu prowadziłaby do sytuacji, że podmioty przejmujące dany zakład pracy lub tylko jego część, a niezatrudniające w dniu przejścia żadnego pracownika, mogłyby dążyć celowo do utrzymania statusu nie-pracodawcy (tzn. nie zatrudniałyby pracowników), aby doprowadzić do wyłączenia stosowania regulacji przepisu art. $23^{1}$ k.p. w ich przypadku. W takim wypadku nowy podmiot mógłby przejąć tylko przedsiębiorstwo, a nie stawałby się stroną z mocy prawa $\mathrm{w}$ dotychczasowych stosunkach pracy. Pracownicy dalej byliby zatrudnieni u dotychczasowego pracodawcy, u którego nie byłoby już praktycznie żadnego majątku. Taka sytuacja najczęściej prowadziłaby do wypowiedzenia pracownikom stosunku pracy przez dotychczasowego pracodawcę. Następnie nowy podmiot, który przejął przedsiębiorstwo, mógłby zatrudnić nawet tych samych pracowników, tylko na innych, gorszych warunkach. $Z$ drugiej strony należy też spojrzeć na interes podmiotu, który chciałby przejąć przedsiębiorstwo wraz z pracownikami, aby móc kontynuować określoną działalność, ale z uwagi na to, że nie jest pracodawca, to nie stosowałoby się przepisu art. $23^{1} \S 1$ k.p. i ex lege nie wstapiłby w nawiązane $\mathrm{u}$ dotychczasowego pracodawcy stosunki pracy. Przedstawiona hipotetyczna sytuacja obrazuje jasno mankamenty użytego przez pracodawcę zwrotu: „w razie przejścia zakładu pracy lub jego części na innego pracodawcę”. Gdyby zatem ustawodawca użył wyrażenia: „w razie przejścia zakładu pracy lub jego części na inny podmiot staje się on z mocy prawa stroną w dotychczasowych stosunkach pracy [...]", nie byłoby powyższych wątpliwości. Pojęcie podmiotu ma znaczenie szersze niż pojęcie pracodawcy, gdyż podmiot nie musi zatrudniać pracowników, może być - przykładowo - tylko osobą fizyczną czy spółką prawa handlowego, która nie zatrudnia pracowników w dniu transferu, a będzie nabywcą zakładu pracy lub jego części.

\footnotetext{
${ }^{23}$ L. MorawSKI, Wstęp do prawoznawstwa, Torun 1998, s. 170.
} 
Zasadne wydaje się nawiązanie do poprzednio obowiązujących przepisów. Regulacje krajowe w zakresie ochrony trwałości stosunku pracy i praw pracowniczych w przypadku różnych przekształceń podmiotowych pracodawcy zostały wprowadzone przez ustawodawcę już w okresie międzywojennym. Przepisy art. 476 Kodeksu zobowiązań z 27 października 1933 r. ${ }^{24}$ i art. 35 rozporządzenia Prezydenta Rzeczpospolitej z 16 marca 1928 r. o umowie o pracę pracowników umysłowych ${ }^{25}$ zawierały $\mathrm{w}$ tej materii istotne postanowienia. W rozporządzeniu z 16 marca 1928 r. o umowie o pracę pracowników umysłowych zamieszczono regulacje, zgodnie z którą w przypadku, kiedy majątek lub przedsiębiorstwo przechodziły w czasie trwania stosunku pracy $\mathrm{w}$ posiadanie innej osoby, stosunek pracy pracowników trwał nadal bez zmiany. Z kolei stosownie do art. $476 \S 1$ Kodeksu zobowiązań w razie przejścia przedsiębiorstwa, gospodarstwa rolnego lub innego zakładu pracy na inną osobę, nabywca wstępował mocą samego prawa w stosunki wynikające $\mathrm{z}$ umów o pracę. Następnie w ustawie z 26 czerwca 1974 r. - Kodeks pracy ustawodawca w ogóle nie przewidywał regulacji dotyczących ochrony stosunku pracy w przypadku przejścia zakładu pracy na innego pracodawcę. Dopiero nowelą z 7 kwietnia 1989 r. $^{26}$ dodano art. $23^{1}$ Kodeksu pracy, który stanowił, iż w razie połączenia zakładów pracy, zakład powstały w wyniku połączenia staje się stroną w stosunkach pracy, których stronami były łączone zakłady. W razie przejęcia zakładu pracy w całości lub w części przez inny zakład, staje się on stroną w stosunkach pracy z pracownikami przejętego zakładu. Natomiast w razie podziału zakładu pracy zakłady powstałe w wyniku podziału stawały się stronami w stosunkach pracy z pracownikami przejętymi z tego zakładu. W doktrynie wskazuje się, że wyliczenie konkretnych przypadków, w których mogło dojść do przejęcia zakładu pracy wynikało z tego, iż wówczas nie zachodziły zbyt duże zmiany gospodarcze na polskim rynku. Koncentrowały się one w dużej mierze na tzw. małej prywatyzacji w handlu oraz zmianach organizacyjnych w sektorze państwowym, takich jak łączenie przedsiębiorstw państwowych lub ich dzielenie, a także udostępnianie części ich mienia innym podmiotom w celu pro-

\footnotetext{
${ }^{24}$ Rozporządzenie Prezydenta Rzeczpospolitej z dnia 27 października 1933 roku - Kodeks zobowiązań (Dz. U. 1933, Nr 82, poz. 598).

${ }^{25}$ Rozporządzenia Prezydenta Rzeczpospolitej z dnia 16 marca 1928 o umowie o pracę pracowników umysłowych (Dz. U. 1928, Nr 35, poz. 323).

${ }^{26}$ Ustawa z dnia 7 kwietnia 1989 roku o zmianie ustawy - Kodeks pracy oraz o zmianie niektórych ustaw (Dz. U. 1989, Nr 20, poz. 107).
} 
wadzenia działalności gospodarczej ${ }^{27}$. Z kolei w roku 1996 nadano nową treść art. $23^{1}$ k.p. ${ }^{28}$ Zmiana wynikła $\mathrm{z}$ potrzeby dostosowania przepisu do zmieniających się warunków na rynku krajowym wskutek procesu reformowania gospodarki związanego z jej prywatyzacją. Ustawodawca zrezygnował z dotychczasowego wyliczania sytuacji faktycznych, w których dochodziło do zmiany pracodawcy w stosunkach pracy ${ }^{29}$. Wprowadzone nowe brzmienie art. $23^{1}$ k.p. pozostawało także $\mathrm{w}$ związku $\mathrm{z}$ rezygnacją $\mathrm{w}$ Kodeksie pracy z pojęcia zakładu pracy $\mathrm{w}$ znaczeniu podmiotowym i zastapienia go kategoria pracodawcy ${ }^{30}$. Obecnie treść art. $23^{1} \S 1$ k.p. wyraźnie stanowi, iż przejście następuje na „innego pracodawcę”, a nie na ,inną osobę” czy „inny podmiot”. Podobnie, z uwagi na definicję legalną pojęcia „pracodawcy” zawartą w kodeksie pracy oraz obecne rozumienie zakładu pracy tylko w znaczeniu przedmiotowym, omawiany przepis art. $23^{1} \S 1$ k.p. nie odzwierciedla regulacji zawartej w kodeksie pracy z roku 1989.

Rozpatrując zakres stosowania przepisu art. $23^{1}$ k.p., konieczne staje się uwzględnienie postanowień dyrektywy 2001/23/WE z dnia 12 marca $2001 \mathrm{r}$. w sprawie zbliżania ustawodawstw Państw Członkowskich odnoszących się do ochrony praw pracowniczych w przypadku przejęcia przedsiębiorstw, zakładów lub części przedsiębiorstw lub zakładów ${ }^{31}$ oraz wykładni jej przepisów dokonanej w orzecznictwie TS, bowiem jest to przepis, za pomocą którego Polska harmonizuje prawo krajowe $\mathrm{z}$ unijnym. Jedną z reguł wykładni systemowej jest obowiązek interpretowania normy prawa wewnętrznego w zgodzie $\mathrm{z}$ normami prawa europejskiego. Zgodnie z art.1 lit. a) dyrektywy 2001/23/WE, dyrektywa ma zastosowanie do każdego przypadku przejścia przedsiębiorstwa, zakładu lub części przedsiębiorstwa, zakładu na innego pracodawcę w następstwie prawnego przejęcia lub łączenia. Z kolei w art. 2 ust. 1 dyrektywy 2001/23/WE znajdują się definicje różnych pojęć. Wśród tych terminów jest „zbywający”, który oznacza każdą osobę fizyczną lub prawną, która w związku z przejściem, w rozumieniu art. 1 ust. 1 dyrektywy 2001/23/WE przestaje być pracodawcą w od-

\footnotetext{
${ }^{27}$ W. SANetra [w:] J. IwUlSki, W. SANETRA, Komentarz do kodeksu pracy, Warszawa 2009, s. 198, 199.

${ }^{28}$ Ustawa z dnia 2 lutego 1996 roku o zmianie ustawy - Kodeks pracy oraz o zmianie niektórych ustaw (Dz.U. 1996, Nr 24, poz. 110).

${ }^{29}$ Z. HAJN, Przejście zakładu pracy na innego pracodawce, [w:] K. RĄCZKA (red.), Prawo pracy po zmianach, Warszawa 1997, s. 117.

${ }^{30}$ W. SANeTRA [w:] J. IwUlSKI, W. SANETRA, Komentarz do kodeksu pracy, s. 199.

${ }^{31}$ Dz. Urz. UE L 82 z 22.03.2001, s. 16.
} 
niesieniu do przedsiębiorstwa, zakładu lub części przedsiębiorstwa lub zakładu, oraz ,przejmujący”, który oznacza każdą osobę fizyczną lub prawną, która z powodu przejścia, w rozumieniu art. 1 ust. 1 dyrektywy 2001/23/WE staje się pracodawcą w odniesieniu do przedsiębiorstwa, zakładu lub części przedsiębiorstwa lub zakładu. W polskiej regulacji nie występuje w treści art. $23^{1} \S 1$ k.p. rozróżnienie na pracodawcę zbywającego i przejmującego, jest tylko mowa o ,innym pracodawcy”. Należy też zwrócić uwagę, iż w literaturze prawa pracy wskazuje się na różnice między przepisami dyrektywy 2001/23/WE a regulacją krajową w zakresie samego przejścia zakładu pracy lub jego części. Dla zrealizowania zmiany pracodawcy prawo polskie nie wymaga, aby transfer miał charakter prawny i aby przejmowana jednostka zachowała swą tożsamość. Wywołuje to wattpliwości co do zgodności z dyrektywą rozszerzenia zakresu regulacji polskiej w porównaniu $\mathrm{z}$ zakresem instytucji przejścia zakładu zakreślonym w dyrektywie ${ }^{32}$.

Dokonując wykładni art. $23^{1} \S 1$ k.p., konieczne wydaje się wzięcie pod uwagę celu tej regulacji (tzw. ratio legis), a zatem skutku, jaki zgodnie z zamierzeniem ustawodawcy, miała ona osiagnąć. Podstawowym celem polskiej regulacji jest ochrona pracowników przed niekorzystnymi dla nich konsekwencjami, jakie moga nastapić na skutek zmian organizacyjnych po stronie pracodawcy ${ }^{33}$. Podobnie głównym celem dyrektywy 2001/23/WE jest ochrona praw pracowniczych w przypadku zmiany pracodawcy, a więc rozwiązania kwestii społecznych związanych ze skutkami przejęcia zakładu pracy ${ }^{34}$.

Badając stanowisko wyrażone w judykaturze przez SN należy wskazać, że sąd podejmował wielokrotnie próbę określenia konstrukcji przejścia zakładu lub jego części na innego pracodawcę, wskazując, iż oznacza to sytuację, ,gdy w wyniku różnego rodzaju zdarzeń prawnych, a nawet faktycznych, zakład pracy (rozumiany jako zorganizowany zespół środków materialnych i niematerialnych, służący realizacji przez pracodawcę konkretnej działalności i stanowiący dla związanych z nim pracowników placówkę zatrudnienia) bądź jego część przechodzi z posiadania jednego podmiotu (dotychczasowego pracodawcy) w posiadanie kolejnego, który wskutek tego staje się pracodawcą dla przejętych

\footnotetext{
${ }^{32}$ Z. HAJN, Przejście zakładu pracy na innego pracodawce $w$ prawie polskim a prawo pracy UE, ,Monitor Prawa Pracy”2004, nr 5, s. 122.

33 I. TwardowsKa-MĘDrEK, Przejście zakładu pracy na innego pracodawcę, Warszawa 2011, s. 231 .

34 Zob. A. DRAL, Powszechna ochrona trwałości stosunku pracy (Tendencje zmian), Warszawa 2009, s. 319 .
} 
pracowników. Konsekwencją transferu jest zatem zmiana pracodawcy i wstapienie nabywcy zakładu w prawa oraz obowiązki zbywcy, będącego do tej pory stroną w stosunkach pracy z załogą"35. W innym orzeczeniu SN odniósł się także do uzasadnienia tej normy prawnej wskazując, że sprowadza się ona do tezy, że ten, kto faktycznie przejmuje zakład pracy w znaczeniu przedmiotowym, przejmuje też zatrudnionych $\mathrm{w}$ nim pracowników, stając się ich pracodawcą ${ }^{36}$. Ponadto, SN rozstrzygając sprawy, w których uznał, że „dalsze trwanie stosunku pracy z pracownikiem, który był zatrudniony przez zmarłego pracodawcę, ma miejsce wówczas, gdy praca była wykonywana w ramach jednostki organizacyjnej, którą można uznać za zakład pracy w znaczeniu przedmiotowym (art. $63^{2} \mathrm{KP}$ w związku z art. $23^{1}$ k.p.)", nie analizuje, czy spadkobiercy w chwili przejścia na nich zakładu pracy byli pracodawcami czy też nie ${ }^{37}$. Podobnie w doktrynie przyjmuje się, iż przejście polega na tym, że zakład pracy lub jego część przechodzi z posiadania jednego podmiotu w posiadanie innego podmiotu, który $\mathrm{w}$ związku $\mathrm{z}$ tym staje się pracodawca przejętych pracowników ${ }^{38}$. T. Liszcz wskazuje również, iż art. $23^{1}$ k.p. odnosi się do wszelkich przypadków, gdy zakład pracy zostaje oddany w całości lub części na własność lub $\mathrm{z}$ innego tytułu do dyspozycji innego podmiotu ${ }^{39}$. $\mathrm{Z}$ kolei $\mathrm{M}$. Tomaszewska uważa, iż przejście z art. $23^{1}$ k.p. oznacza, że zakład pracy (bądź jego część) przechodzi $\mathrm{z}$ posiadania jednego podmiotu (dotychczasowego pracodawcy) w posiadanie kolejnego, który wskutek tego staje się pracodawcą dla przejętych pracowników. Autorka wyjaśnia, iż konsekwencją tego transferu jest: zmiana pracodawcy i wejście nabywcy w rolę nowego pracodawcy wobec wszystkich pracowników, którzy byli związani z działalnością przejmowanego zakładu pracy, wstapienie nabywcy zakładu w prawa i obowiązki zbywcy, będącego do tej pory stroną $\mathrm{w}$ stosunkach pracy $\mathrm{z}$ załoga, odpowiedzialność in solidum dotychczasowego i nowego pracodawcy ${ }^{40}$. Tak więc zarówno w orzecznictwie, jak i w doktrynie wyrażenie: „na innego pracodawcę” użyte w art. $23^{1} \S 1$ k.p.

\footnotetext{
${ }^{35}$ Wyrok SN z dnia 19 października 2010 roku, sygn. akt. I PK 91/10, Legalis nr 309849.

${ }^{36}$ Wyrok SN z dnia 29 sierpnia 1995 r., sygn. akt I PRN 38/95, LEX nr 23557.

${ }^{37}$ Wyrok SN z dnia 8 marca 2012 roku, sygn. akt III UK 58/11, OSNP 2013, nr 5-6, poz. 61, LEX nr 1289166; zob. także uchwała SN z dnia 22 lutego 1994 roku, sygn. akt I PZP 1/94, Legalis nr 28457.

${ }^{38}$ Z. HAJN, Nowa regulacja przejścia zakladu pracy na innego pracodawce, „Praca i Zabezpieczenie Społeczne” 1996, nr 10, s. 18; zob. także A. TOMANEK, Przejście zakładu pracy na innego pracodawce, Wrocław 2002, s. 43.

${ }^{39}$ T. Liszcz, Prawo pracy, s. 112.

${ }^{40}$ M.TomaszewsKa [w:], K.W. BARAn (red.), Kodeks pracy, s. 184.
} 
jest interpretowane szerzej, niż definicja legalna samego terminu pracodawcy zamieszczona $\mathrm{w}$ art. 3 Kodeksu pracy. Jednak należy podkreślić, że przyjmując tylko wykładnie językową przepisu art. $23^{1} \S 1$ k.p., nie można wywieść takiego wniosku, gdyż pracodawcą nie jest podmiot, który nie zatrudnia pracowników.

\section{PODSUMOWANIE}

Stosownie do treści art. $23^{1} \S 1$ k.p. w razie przejścia zakładu pracy lub jego części na innego pracodawcę, pracodawca ten staje się z mocy prawa stroną w dotychczasowych stosunkach pracy. Analizowana problematyka dotyczy przypadku, kiedy podmiot przejmujący zakład pracy lub tylko jego cześć w dniu przejścia nie posiada jeszcze statusu pracodawcy, gdyż nie zatrudnia pracowników, a staje się nim dopiero z chwila, kiedy nastapiło przejście. Definicja pojęcia pracodawcy wyraźnie stanowi, iż aby jednostkę organizacyjna, choćby nie posiadała osobowości prawnej, a także osobę fizyczną, uznać za pracodawcę, muszą one zatrudniać pracowników. Jednakże w tym wypadku nie można interpretować przepisu art. $23^{1} \S 1$ k.p. tylko uwzględniając reguły wykładni językowej, ponieważ znaczenie literalne prowadzi do nieuzasadnionych z punktu widzenia społecznego i ekonomicznego konsekwencji. Jak już wspomniano, podmioty przejmujące dany zakład pracy lub tylko jego cześć, a niezatrudniające w dniu przejścia żadnego pracownika, mogłyby dążyć celowo do utrzymania statusu nie-pracodawcy (tzn. nie zatrudniałyby pracowników), aby doprowadzić do wyłączenia stosowania regulacji art. $23^{1}$ k.p. w ich przypadku. Podkreślić należy, iż podstawowym celem prawnej regulacji transferu zarówno na gruncie wspólnotowym, jak i krajowym jest łagodzenie wpływu przekształceń podmiotowych po stronie pracodawcy na sytuacje pracowników ${ }^{41}$. Instytucja ta została wprowadzona przez ustawodawcę do kodeksu pracy po to, aby służyć ochronie nabytych praw pracowniczych wynikających ze stosunku pracy u dotychczasowego pracodawcy. W tym wypadku wydaje się, iż zastosowanie powinny znaleźć reguły wykładni celowościowej i prounijnej wykładni prawa krajowego. Konieczne staje się uwzględnienie przede wszystkim funkcji ochronnej tej normy względem pracownika oraz interpretowanie tego przepisu w zgodzie z normami prawa europejskiego.

\footnotetext{
${ }^{41}$ Ł. PISARCZYK, Przejście zakładu pracy lub jego części na innego pracodawce - wybrane problemy, „Praca i Zabezpieczenie Społeczne” 2007, nr 5, s. 15.
} 
Reasumując powyższe wywody, właściwe wydaje się postawienie tezy, że zastosowanie instytucji przejścia zakładu pracy lub jego części na innego pracodawcę, obejmuje także sytuacje, kiedy nowy podmiot przejmujący zakład pracy lub tylko jego część stanie się pracodawcą dopiero w wyniku przejęcia pracowników od dotychczasowego pracodawcy. Niemniej, de lege ferenda, zasadny jest postulat o zmianę wyrażenia: „na innego pracodawcę” .

\section{BIBLIOGRAFIA}

\section{AKTY NORMATYWNE}

Dyrektywa 2001/23/WE z dnia 12 marca 2001 roku w sprawie zbliżania ustawodawstw Państw Członkowskich odnoszących się do ochrony praw pracowniczych w przypadku przejęcia przedsiębiorstw, zakładów lub części przedsiębiorstw lub zakładów, Dz. Urz. UE L 82 z 22.03.2001.

Ustawa z dnia 11 marca 2004 roku o podatku od towarów i usług, Dz. U. 2011, Nr 177, poz. 1054 z późn. zm.

Ustawa z dnia 7 kwietnia 1989 roku o zmianie ustawy - Kodeks pracy oraz o zmianie niektórych ustaw, Dz. U. 1989, Nr 20, poz. 107.

Ustawa z dnia 26 lipca 1991 roku o podatku dochodowym od osób fizycznych, Dz. U. 2012, poz. 361 z późn. zm.

Ustawa z dnia 15 lutego 1992 roku o podatku dochodowym od osób prawnych, Dz. U. 2014, poz. 851 z póź. zm.

Ustawa z dnia 2 lutego 1996 roku o zmianie ustawy - Kodeks pracy oraz o zmianie niektórych ustaw, Dz. U. 1996, Nr 24, poz. 110 z późn. zm.

Ustawa z dnia 15 września 2000 roku - Kodeksu spółek handlowych, Dz. U. 2013, poz. 1030 z późn. zm.

Ustawa z dnia 26 czerwca 1974 roku - Kodeks pracy, Dz. U. 2014, poz. 1502 z późń. zm.

Rozporządzenia Prezydenta Rzeczpospolitej z dnia 16 marca 1928 o umowie o pracę pracowników umysłowych, Dz. U. 1928, Nr 35, poz. 323 z późn. zm.

Rozporządzenie Prezydenta Rzeczpospolitej z dnia 27 października 1933 roku Kodeks zobowiązań, Dz. U. 1933, Nr 82, poz. 598 z późn. zm.

\section{ORZECZENIA}

Wyrok SN z dnia 19 stycznia 1993 roku, sygn. akt I PZP 70/92, LexPolonica nr 300595. Uchwała SN z dnia 22 lutego 1994 roku, sygn. akt I PZP 1/94, Legalis nr 28457. 
Wyrok SN z dnia 2 października 1996 roku, sygn. akt I PRN 72/96, LexPolonica nr 314288, LEX nr 27469.

Wyrok SN z dnia 20 listopada 1996 roku, sygn. akt I PKN 21/96, LEX nr 192324.

Wyrok SN z dnia 23 lutego 1999 roku, sygn. akt I PKN 594/98, LEX nr 37482.

Wyrok SN z dnia 3 kwietnia 2007 roku, sygn. akt II PK 245/2006, LexPolonica nr 1631760.

Wyrok SN z dnia 20 października 2009 roku, sygn. akt I PK 96/2009, LexPolonica nr 2375700, Legalis nr 288285.

Wyrok SN z dnia 9 marca 2010 roku, sygn. akt I UK 326/2009, LexPolonica nr 2396068.

Wyrok SN z dnia 19 października 2010 roku, sygn. akt I PK 91/10, Legalis nr 309849.

Wyrok SN z dnia 21 stycznia 2011 roku, sygn. akt II PK 223/10, Legalis nr 417505.

Wyrok SN z dnia 8 marca 2012 roku, sygn. akt III UK 58/11, OSNP 2013, nr 5-6, poz. 61, LEX nr 1289166.

\section{LITERATURA}

BARAN Krzysztof W. (red.): Kodeks pracy. Komentarz, Wolters Kluwer Polska, Warszawa 2012.

DRAL Antoni: Powszechna ochrona trwałości stosunku pracy (Tendencje zmian), Wolters Kulwer Polska, Warszawa 2009.

GAwliK Zdzisław [w:] Andrzej KidyBA (red.): Kodeks cywilny. Komentarz, t. I: Część ogólna, LEX, Warszawa 2012.

HAJN Zbigniew: Nowa regulacja przejścia zakładu pracy na innego pracodawcę, „Praca i Zabezpieczenie Społeczne" 1996 , nr 10.

HAJN Zbigniew: Pojęcie pracodawcy po nowelizacji kodeksu pracy, „Praca i Zabezpieczenie Społeczne" 1997, nr 5-6.

HAJN Zbigniew: Przejście zakładu pracy na innego pracodawcę, [w:] K. RĄCZKA (red.), Prawo pracy po zmianach, Polskie Wydawnictwo Ekonomiczne, Warszawa 1997.

HAJN Zbigniew: Przejście zakładu pracy na innego pracodawcę w prawie polskim a prawo pracy UE, „Monitor Prawa Pracy” 2004, nr 5.

IWULSKI Józef, SANETRA Walerian: Komentarz do Kodeksu pracy, LexisNexis, Warszawa 2009.

Liszcz Teresa: Prawo pracy, LexisNexis, Warszawa 2014.

MoRAWSKI Lech: Wstęp do prawoznawstwa, TNOiK, Toruń 1998.

MUSZALSKI Wojciech (red.): Kodeks pracy. Komentarz, C.H.Beck, Warszawa 2011.

NADSKAKULSKI Robert: Część zakładu pracy w rozumieniu wybranych przepisów prawa pracy, „Praca i Zabezpieczenie Społeczne” 1995, nr 10.

PISARCZYK Łukasz: Przejście zakładu pracy lub jego części na innego pracodawcę wybrane problemy, „Praca i Zabezpieczenie Społeczne” 2007, nr 5.

GERSDORF Małgorzat, Krzysztof RĄCZKA, Jacek SKOCZYŃSKI: Kodeks pracy. Komentarz, (Wielkie Komentarze), LexisNexis, Warszawa 2011.

SANETRA Walerian: O pojęciu części zakładu pracy, „Przegląd Sądowy” 1994, nr 1. 
SoBCZYK Arkadiusz: Uwagi na temat praw pracodawcy w polskim prawie pracy, Studia z zakresu prawa pracy i polityki społecznej 1995.

Stelina Jakub [w:] Arkadiusz SoBCzYK (red.), Dominika DöRRE-KolasA, Monika GŁADOCH, Paweł Korus, Leszek Mitrus, Maciej ZiEleniecKi, Kodeks pracy. Komentarz, C.H. Beck, Warszawa 2015.

SuKNAROWSKA-DrZEWIECKA Ewa [w:] Krzysztof WALCZAK (red.): Kodeks pracy. Komentarz, C.H. Beck, Warszawa 2015.

ŚWIĄTKOWSKI Andrzej: Kodeks pracy. Komentarz, C.H. Beck, Warszawa 2010.

TOMANEK Artur: Przejście zakładu pracy na innego pracodawcę, Wydawnictwo Uniwersytetu Wrocławskiego, Wrocław 2002.

TWARDOWSKA-MĘDREK Izabela: Przejście zakładu pracy na innego pracodawcę, Wydawnictwo Uniwersytetu Wrocławskiego, LEX, Warszawa 2011.

WĄŻ Piotr: Koncepcja pracodawcy rzeczywistego w świetle art. 3 KP, „Monitor Prawa Pracy" 2007, nr 3.

WRATNY Jerzy: Kodeks pracy. Komentarz, C.H. Beck, Warszawa 2013.

ZAWIRSKA Patrycja, Magdalena ZWOLIŃSKA: Proeuropejska wykładnia pojęcia przejścia zakładu pracy - kryterium tożsamości, „Monitor Prawa Pracy” 2010, nr 8.

\section{POJECCIE PRACODAWCY W RAZIE PRZEJŚCIA ZAKŁADU PRACY}

\section{STRESZCZENIE}

Celem artykułu jest zwrócenie uwagi na znaczenie pojęcia pracodawcy w kontekście przejścia zakładu pracy lub jego części na innego pracodawcę i możliwość zastosowania wykładni celowościowej i prounijnej. Za ,pracodawcę”, zgodnie z art. 3 k.p., uważana jest każda jednostka organizacyjna, chociażby nie posiadała osobowości prawnej, a także osoba fizyczna, jeżeli zatrudniają one pracowników. Jednakże w obrocie gospodarczym dochodzi do transakcji, gdzie stronami są podmioty, które w dniu przejścia nie mają statusu pracodawcy, gdyż nie zatrudniają pracowników, a pracodawcą stają się dopiero w wyniku właśnie przejścia zakładu pracy lub tylko jego części. W takiej sytuacji występują wątpliwości, jak należy rozmieć znaczenie ,innego pracodawcy”, o którym mowa w art. $23^{1} \S 1$ k.p. W artykule zwrócono uwagę, że dokonanie tylko wykładni językowej tego przepisu, która to wykładnia w państwach demokratycznych zajmuje uprzywilejowana pozycję wobec wykładni systemowej i funkcjonalnej, jest w tym wypadku nieuzasadnione. W wyniku takiej interpretacji podmioty przejmujące dany zakład pracy lub tylko jego część, a niezatrudniające w dniu przejścia żadnego pracownika, mogłyby dążyć celowo do utrzymania statusu nie-pracodawcy (tzn. nie zatrudniałyby pracowników), aby doprowadzić do wyłaczenia stosowania regulacji art. $23^{1}$ k.p. w ich przypadku. W tej sytuacji uzasadnione jest zastosowanie wykładni celowościowej i prounijnej przy interpretacji tego przepisu. Zastosowanie instytucji przejścia zakładu pracy lub jego części na innego pracodawcę obejmuje także sytuacje, kiedy nowy podmiot przejmujący zakład pracy lub tylko jego część stanie się 
pracodawcą dopiero w wyniku przejęcia pracowników od dotychczasowego pracodawcy.

Słowa kluczowe: zakład pracy, przedsiębiorstwo, zorganizowana część przedsiębiorstwa, transfer zakładu pracy na nowego pracodawcę, jednostka organizacyjna, osoba fizyczna, wykładnia celowościowa, wykładnia prounijna

\title{
THE NOTION OF 'EMPLOYER' IN THE SITUATION OF EMPLOYING ESTABLISHMENT TAKEOVER
}

\begin{abstract}
SUMMARY
The aim of the article is to turn one's attention to the notion of employer in the context of transfer of an employing establishment or its part onto another employer and the possibility to apply functional and pro-union interpretation. According to article 3 of the Labor Code an "employer" is considered to be every organizational entity, even if it does not possess legal personality, as well as a natural person, if they employ workers. However, in business trading, there exist transactions where the parties are the entities which, on the day of the takeover, do not have the status of an employer as they do not employ workers, and they become the employer exactly as a result of the transfer of an employing establishment or only its part. Therefore, in such a situation there may appear some doubts how to interpret the meaning of "another employer", as stated in article $23^{1} \S 1$ LC. It was emphasized in the article that making a solely literal interpretation of this provision, which interpretation in democratic countries occupies a privileged position compared to functional and contextual interpretation, is unjustified in this case. As a result of such an interpretation, entities taking over a given employing establishment or only its part and not employing any worker on the day of the takeover, could intentionally aim to maintain the status of non-employer (i.e. not employ workers), to lead to the exclusion of applying the provisions of article $23^{1} \S 1 \mathrm{LC}$ in their case. In this situation it is justified to apply functional and pro-union interpretation when constructing this provision. Applying the institution of the takeover of an employing establishment or its part by another employer also covers situations when a new entity taking over an employing establishment or its part, becomes an employer only as a result of taking over workers from the previous employer.
\end{abstract}

Key words: employing establishment, enterprise, organized part of enterprise, transfer of employing establishment onto a new employer, organizational entity, natural person, functional interpretation, pro-union interpretation 